\title{
Liver Injury with Features Mimicking Autoimmune Hepatitis following the Use of Black Cohosh
}

\author{
Grace Guzman, ${ }^{1}$ Eric R. Kallwitz, ${ }^{2}$ Christina Wojewoda, ${ }^{3}$ Rohini Chennuri, ${ }^{1}$ Jamie Berkes, ${ }^{2}$ \\ Thomas J. Layden, ${ }^{2}$ and Scott J. Cotler ${ }^{2}$
}

${ }^{1}$ Department of Pathology, University of Illinois, Chicago, IL 60612, USA

${ }^{2}$ Department of Medicine, University of Illinois, Chicago, IL 60612, USA

${ }^{3}$ Department of Pathology, Case Western Reserve University, Cleveland, OH 44106, USA

Correspondence should be addressed to Grace Guzman,graceguz@uic.edu

Received 21 July 2009; Accepted 11 November 2009

Recommended by Anne M. Larson

\begin{abstract}
There are a growing number of cases detailing acute hepatic necrosis in patients taking black cohosh (Cimicifuga racemosa), an over-the-counter herbal supplement for management of menopausal symptoms. Our aim is to illustrate two cases of liver injury following the use of black cohosh characterized by histopathological features mimicking autoimmune hepatitis. Both patients reported black cohosh use for at least six months and had no evidence of another cause of liver disease. Their liver biopsies showed a component of centrilobular necrosis consistent with severe drug-induced liver injury. In addition, the biopsies showed characteristics of autoimmune-like liver injury with an interface hepatitis dominated by plasma cells. Although serum markers for autoimmune hepatitis were not particularly elevated, both patients responded to corticosteroids, supporting an immune-mediated component to the liver injury. Liver injury following the use of black cohosh should be included in the list of differential diagnoses for chronic hepatitis with features mimicking autoimmune hepatitis.
\end{abstract}

Copyright () 2009 Grace Guzman et al. This is an open access article distributed under the Creative Commons Attribution License, which permits unrestricted use, distribution, and reproduction in any medium, provided the original work is properly cited.

\section{Introduction}

Black cohosh (Cimicifuga racemosa) is an herbal supplement that is sold over-the-counter for management of menopausal symptoms, menstrual irregularities, and arthritis. There are now a number of manuscripts indicating liver injury from black cohosh [1-7]. Here, we present two patients who developed a drug-induced liver injury following the use of black cohosh characterized by centrilobular necrosis and histologic features mimicking autoimmune hepatitis (AIH) who improved with corticosteroid therapy.

\section{Case Studies}

The case series was approved by the Institutional Review Board at the University of Illinois at Chicago.

Case 1. A 42-year-old woman presented to her primary care provider with a two-month history of progressive malaise, nausea, vomiting, and dizziness. On physical examination, she had mild icterus and no stigmata of chronic liver disease. Her only comorbidity was hypothyroidism. Her medications included black cohosh, which she was taking for 6 months, and levothyroxine $0.05 \mathrm{mg}$ daily. She discontinued black cohosh when her symptoms began. She had no family history of liver or autoimmune disease. She denied any alcohol or drug use. Her total bilirubin level was $3.1 \mathrm{mg} / \mathrm{dL}$ (normal 0.8-1.2), alanine transaminase (ALT) $1457 \mathrm{U} / \mathrm{L}$ (normal 540), aspartate transaminase (AST) 696 U/L (normal 10-40), alkaline phosphatase (ALP) 94 U/L (normal 30-120 U/L), and international normalized ratio (INR) 1.2 (normal 0.8 1.2). Further laboratories showed no serological evidence of active hepatitis A, B, or C infection. Serological titers for acute cytomegalovirus (CMV) and Epstein Barr virus (EBV) were negative. Antinuclear antibody (ANA) was 1 : 40 and smooth muscle antibody was modestly elevated at 1 : 80 . Serum iron was $169 \mu \mathrm{g} / \mathrm{dL}$ (normal: 50 to $170 \mu \mathrm{g} / \mathrm{dL}$ for women), ferritin was $642 \mathrm{ng} / \mathrm{dL}$ (normal: 15-200 ng/mL for females), and hemochromatosis gene analysis was negative. Ceruloplasmin was in the normal range. 


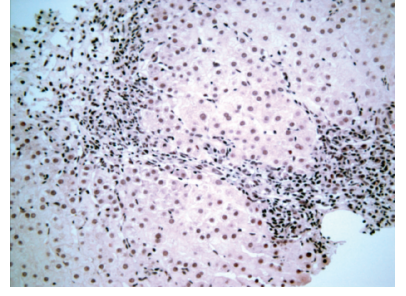

(a)

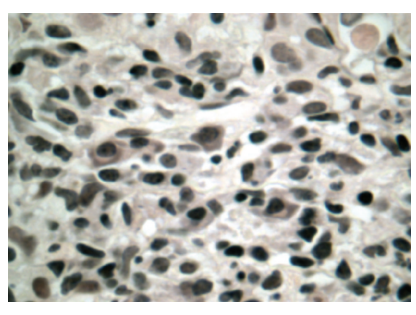

(b)
Figure 1: This liver biopsy from Case 1 displays chronic hepatitis remarkable for its dense interface activity with cholangiolar proliferation (1a) $(\times 200)$ and sheets of plasma cells and apoptosis (1b) $(\times 600)$.

Four months after her initial presentation, the liver enzymes remained elevated with an ALT of $334 \mathrm{U} / \mathrm{L}$, AST $229 \mathrm{U} / \mathrm{L}$, and a total bilirubin of $1.4 \mathrm{mg} / \mathrm{dL}$. A liver biopsy was performed which prompted a referral to the liver center at the University of Illinois. The liver biopsy was remarkable for necrosis around terminal hepatic venules, lobular disarray, mild ballooning, apoptosis, Kupffer cell reactivity, mild cholangiolar proliferation, and interface hepatitis remarkable for numerous plasma cells and eosinophils. A repeat antismooth muscle antibody was normal at $1: 20$. Prednisone treatment was initiated. A follow-up liver biopsy was performed after three months. At this time, the liver histology demonstrated chronic hepatitis with fibroinflammatory expansion of portal tracts by moderate plasma cell rich interface hepatitis, rare periportal hepatocyte apoptosis, and mild cholangiolar proliferation (Figures 1(a) and 1(b)). The patient was started on azathioprine. Her liver enzymes returned to normal values within five months with an ALT of $30 \mathrm{U} / \mathrm{L}$, AST of $29 \mathrm{U} / \mathrm{L}$, ALP $36 \mathrm{U} / \mathrm{L}$, and a total bilirubin of $0.9 \mathrm{mg} / \mathrm{dL}$. A repeat liver biopsy after fifteen months showed marked improvement with only minimal portal lymphocytes and no other significant histopathological changes. The liver function test values remained normal at 15 months and at 40 months following the acute episode. The clinicopathological features of Case 1 are illustrated in Tables 1, 2, and 3.

Case 2. A 53-years-old woman presented to our liver center for evaluation of elevated liver enzymes detected at a health screening fair four months earlier. She had no risk factors for viral hepatitis, no family history of liver disease, and denied any alcohol consumption. Although she was initially asymptomatic, she developed right upper quadrant abdominal pain, fatigue, and lower extremity edema by the time of her presentation. Her medical history was remarkable only for irritable bowel syndrome. Her medications within the past year included dicyclomine for abdominal cramps as needed, an herbal supplement which contains soy protein and black cohosh for menopausal symptoms, and occasional over the counter nonsteroidal anti-inflammatory drugs (NSAIDs) for pain. She discontinued these medications on the advice of her primary care physician. Laboratories showed a total bilirubin of $2.0 \mathrm{mg} / \mathrm{dL}$, ALT $443 \mathrm{U} / \mathrm{L}$, AST $478 \mathrm{U} / \mathrm{L}$, ALP $188 \mathrm{U} / \mathrm{L}$, and an INR of 2.0. Other notable laboratory values included negative serological evidence of active hepatitis $\mathrm{A}, \mathrm{B}$, and $\mathrm{C}$ viral infection, undetectable hepatitis $\mathrm{C}$ virus RNA by PCR, iron $137 \mu \mathrm{g} / \mathrm{dL}$, ferritin $1527 \mathrm{ng} / \mathrm{mL}$, negative hemochromatosis gene analysis, and nonsignificant ceruloplasmin level. Serological tests for antinuclear, antismooth muscle, antiliver kidney microsomal, and antimitochondrial antibodies were negative. An ultrasound demonstrated patent portal and hepatic veins and a normal appearing liver. Her liver biopsy was remarkable for centrilobular necrosis with moderate cholangiolar proliferation and plasma cell rich interface and lobular hepatitis.

The patient was started on $40 \mathrm{mg}$ of prednisone daily. Liver function test values improved to a total bilirubin of $1.4 \mathrm{mg} / \mathrm{dL}$, ALT of $60 \mathrm{U} / \mathrm{L}$, AST 50 U/L, and ALP $153 \mathrm{U} / \mathrm{L}$ after two weeks and normalized after five weeks of therapy. The clinicopathological features of Case 2 are illustrated in Tables 1, 2, and 4 .

\section{Application of the Naranjo Causality Score for Adverse Drug Reactions}

The Naranjo causality score for adverse drug reactions [8] was applied to the cases described here. As shown in Table 5, the current case studies individually achieved a Naranjo score of 3 and were both categorized as "possible adverse drug reaction", in a scale encompassing a minimum score of zero, or "doubtful adverse drug reaction" to a maximum score of $\geq 9$, or "definite adverse drug reaction."

\section{Application of the Hennes-Simplified Criteria for Diagnosis of Autoimmune Hepatitis (AIH)}

While the current case studies showed histopathological features of autoimmune hepatitis, neither fulfilled a diagnosis of "probable AIH" or "definite AIH" based on the Hennes simplified criteria for diagnosis of AIH [10]. Briefly, Case 1 had an ANA titer of up to 1 : 80 (score 2), no available immunoglobulin titers (no score), a liver histology compatible with AIH (score 1), and absence of viral hepatitis (score 2), with a total score of 5 . Case 2 had a score of 1-0-1-2 $=4$, on a scale where a score of $\geq 6$ was designated "probable AIH", and $\geq 7$ as "definite AIH."

\section{Discussion}

Botanical dietary supplements are used commonly in the United States and are generally perceived to be safe [11]. In one study, nearly one half of persons reported use of at least one agent to their primary provider [12]. A major difficulty in studying black cohosh is uncertainty regarding the composition of the various black cohosh products. Black cohosh itself contains a number of secondary compounds including phenolic derivatives and triterpene glycosides [13]. Phytoestrogens were postulated to play a role in black cohosh binding to estrogen receptors, but the presence of these compounds is controversial. In one study, chromatographic analysis of 11 commercial black 
TABLE 1: Current case studies: clinical features and medications.

\begin{tabular}{lcc}
\hline Clinical features & Case 1 & Case 2 \\
\hline Age (years) & 42 & 53 \\
Gender & Female & Female \\
Signs & Mild icterus & Increased LFTs \\
Symptoms & Progressive malaise, nausea & Vomiting, dizziness \\
& Absent & Lower extremity edema \\
Stigmata of CLD & Black cohosh & Absent \\
\hline Medications & Menopausal symptoms & OTC with soy and black cohosh \\
\hline Indication & Not specified & Menopausal symptoms \\
Dose & 6 months & Not specified \\
Duration & Levothyroxine & 8 months \\
\hline Other medications & Hyperthyroidism & Dicyclomine; NSAID \\
\hline Indication & 0.05 mg daily & GI cramps; pain \\
Dose & Chronic & Not specified \\
Duration & & As needed
\end{tabular}

LFTs: Liver function tests.

RUQ: Right upper quadrant.

CLD: Chronic liver disease.

OTC: Over the counter drug.

NSAID: Nonsteroidal anti-inflammatory drug.

TABLE 2: Current case studies: past medical history, serological tests, and other pertinent laboratory data.

\begin{tabular}{|c|c|c|c|}
\hline & & Case 1 & Case 2 \\
\hline \multirow{2}{*}{ Past medical history } & Viral or non-viral hepatitis & Absent & Absent \\
\hline & Alcohol consumption & Absent & Absent \\
\hline \multirow{11}{*}{ Serological tests } & Anti-HAV IgM & Absent & Absent \\
\hline & Anti-HAV total & Absent & Absent \\
\hline & HBV surface antigen & Absent & Absent \\
\hline & Anti-HBV core & Absent & Absent \\
\hline & Anti-HBV surface & Absent & Absent \\
\hline & Anti-HCV & Absent & Absent \\
\hline & EBV Ca IgM & Absent & Absent \\
\hline & EBV Ca IgG & Absent & Absent \\
\hline & EBV Na IgG & Absent & Absent \\
\hline & EBV IgG & Absent & Absent \\
\hline & Anti-CMV IgM & Absent & Absent \\
\hline HCV RNA PCR & & Negative & Negative \\
\hline \multirow{4}{*}{ Other laboratory values } & Iron (normal: $50-70 \mu \mathrm{g} / \mathrm{dL}$ for women) & $169 \mu \mathrm{g} / \mathrm{dL}$ & $137 \mu \mathrm{g} / \mathrm{dL}$ \\
\hline & Ferritin (normal: $15-200 \mathrm{ng} / \mathrm{mL}$ in women) & $642 \mathrm{ng} / \mathrm{mL}$ & $1527 \mathrm{ng} / \mathrm{mL}$ \\
\hline & HFE gene analysis & Negative & Negative \\
\hline & Ceruloplasmin & Normal & Normal \\
\hline
\end{tabular}

cohosh products showed that three were actually Asian Actea species [13]. An analysis of the remaining eight products found variability in the composition of triterpene glycosides and phenolic constituents. More importantly, not a single product contained a phytoestrogen. Thus, the mechanism by which black cohosh might impact on alleviating menopausal symptoms is not well understood. Other possibilities include binding to yet-to-be-defined receptors or effects on the central nervous system [14]. Whether black cohosh is effective in controlling vasomotor symptoms of menopause is controversial as well. The American College of Obstetrics and Gynecology included black cohosh as a possible remedy for the vasomotor symptoms of menopause [15]. A large randomized-blinded trial of one-year duration found no difference between black cohosh and placebo in controlling vasomotor symptoms [16]. Moreover, a recent review did not recommend long-term use due to the absence of safety evaluation [17].

There are a growing number of case reports of hepatotoxicity in patients taking black cohosh (Table 6) [17]. Most described acute hepatic necrosis, although three articles of them detailed a case with clinical features of 
TABLE 3: Duration of Illness and black cohosh use, liver function tests, autoimmune markers, histology, and treatment.

\begin{tabular}{|c|c|c|c|c|c|c|}
\hline \multicolumn{7}{|c|}{ Case 1} \\
\hline \multicolumn{7}{|l|}{ Time of use to illness: $6 \mathrm{mo}^{* *} \downarrow$} \\
\hline \multicolumn{7}{|l|}{ Time of use to discontinuation: $6 \mathrm{mo}^{* *} \downarrow$} \\
\hline Time of presentation to the liver clinic ${ }^{*}$ & & $* \downarrow$ & & & & \\
\hline Duration of illness in months & 2 & 4 & 7 & 12 & 15 & 40 \\
\hline Treatment & - & Prednisone & Azathioprine & - & - & - \\
\hline \multicolumn{7}{|l|}{ Liver function tests (normal) } \\
\hline Total bilirubin $(0.8-1.2 \mathrm{mg} / \mathrm{dL})$ & 3.1 & 1.4 & 1.8 & 0.9 & 1.0 & 0.8 \\
\hline $\operatorname{ALT}(5-40 \mathrm{U} / \mathrm{L})$ & 1457 & 334 & 321 & 30 & 39 & 37 \\
\hline AST (10-40 U/L) & 696 & 229 & 236 & 29 & 37 & 33 \\
\hline $\operatorname{ALP}(30-120 \mathrm{U} / \mathrm{L})$ & 94 & 68 & 66 & 36 & 38 & 37 \\
\hline $\operatorname{INR}(0.8-1.2)$ & 1.2 & 1.17 & - & 0.95 & - & 0.92 \\
\hline \multicolumn{7}{|l|}{ Autoimmune antibodies } \\
\hline Antinuclear antibody & $1: 40$ & $1: 20$ & - & - & - & - \\
\hline Antismooth muscle antibody & $1: 80$ & - & - & - & - & - \\
\hline Liver biopsy findings & 一 & Acute hepatitis & Chronic hepatitis & - & & Biopsy at 15 mo. \\
\hline \multicolumn{7}{|l|}{ Lobular } \\
\hline Necrosis & - & Central \& portal & - & - & & Absent \\
\hline Infiltrates & - & Mixed with eosinophils & Plasmacytic & - & & Absent \\
\hline Other findings & 一 & Disarray, ballooning Apoptosis & & - & No & significant abnormality \\
\hline \multicolumn{7}{|l|}{ Portal and periportal } \\
\hline Cholangiolar proliferation & - & Moderate & Moderate & - & & Absent \\
\hline Infiltrate severity & - & Moderate & Moderate & - & & Minimal \\
\hline Infiltrate predominant type & - & Mixed with eosinophils & Plasmacytic & - & & Lymphocytes \\
\hline Fibrosis & - & Fibronecrosis & Fibronecrosis & - & & Absent \\
\hline
\end{tabular}

autoimmune hepatitis after black cohosh use $[1,2,5]$. The clinicopathological features of the cases in the current series have a fascinating combination of findings. Both patients presented with an acute hepatitis displaying prominent centrilobular necrosis consistent with severe drug-induced liver injury. While autoantibodies were low titer or absent, the histology showed characteristics of autoimmune hepatitis with a plasma cell rich interface and lobular hepatitis. In addition, both patients responded to corticosteroids, supporting an immune mediated component to the liver injury.

Determining the risk of black cohosh hepatotoxicity is further complicated by variability in both dosage and number of other botanical herbal supplements contained in some preparations. As an example, in the case reported by Lontos [4], the preparation of black cohosh included 4 other botanicals: ground ivy, golden seal, gingko, and oat seeds. While liver injury remains unreported with the use of the last 3 botanicals, ground ivy contains a known hepatotoxin, pulegone. This case culminated in liver failure despite discontinuation of the herbal supplement [4].

Drug interactions might further potentiate negative outcomes resulting from hepatoxicity due to herbal supplements. That subjects in 3 of 5 reported cases of autoimmunelike liver injury following consumption of black cohosh (Table 6) also had concomitant intake of synthetic thyroid hormone, levothyroxine, merits attention [2, 5]. Herbal supplements such as venencapsan and black cohosh, and prescription drugs specifically rosiglitazone, ritonavir, and valproic acid, have had reported drug interactions with levothyroxine $[1,9,18-22]$.

A 2008 review by Mahady assigned all known case reports of black cohosh-induced liver injury under the category of "possible causality" [9]. As earlier stated, both cases of the current study were also assigned "possible causality" by Naranjo scale [8]. Although no clinical or animal pharmacokinetic or toxicological information were identified in the Mahady review, it led to the inclusion of a cautionary statement on black cohosh products which was not previously required [9]. Despite such development, the use of botanical dietary supplements is generally viewed by the public as safe [11]. Providers are encouraged to screen patients about their consumption of botanical herbal supplements and to assess for any evidence of liver injury [1]. Timely discontinuation of hepatotoxic agents and, in some cases, early initiation of immunotherapy might prevent significant liver injury or could even be life saving [4].

The validity of reported cases of liver injury due to black cohosh illustrated in Table 6 has been disputed. Concerns that led to this uncertainty included cases in which the timing of liver injury occurred at a relatively short interval following exposure to black cohosh $[2,6,7]$, presence of comorbidities such as cholelithhiasis [6] or concomittant use of drugs other than black cohosh that could have potentially 
TABle 4: Duration of Illness and black cohosh use, liver function tests, autoimmune markers and histology.

\begin{tabular}{|c|c|c|c|}
\hline \multicolumn{4}{|c|}{ Case 2} \\
\hline Time of use to illness: 8 months* & $* \downarrow$ & & \\
\hline Time of use to discontinuation: 8 months* & $* \downarrow$ & & \\
\hline Time of presentation to liver clinic* & & $* \downarrow$ & \\
\hline Duration in months & 4 & 4.5 & 5 \\
\hline Treatment & & Prednisone & \\
\hline \multicolumn{4}{|l|}{ Liver function tests (normal values) } \\
\hline Total bilirubin $(0.8-1.2 \mathrm{mg} / \mathrm{dL})$ & 2.0 & 1.4 & 0.6 \\
\hline $\operatorname{ALT}(5-40 \mathrm{U} / \mathrm{L})$ & 443 & 60 & 30 \\
\hline $\operatorname{AST}(10-40 \mathrm{U} / \mathrm{L})$ & 478 & 50 & 38 \\
\hline $\operatorname{ALP}(30-120 \mathrm{U} / \mathrm{L})$ & 188 & 153 & 98 \\
\hline $\operatorname{INR}(0.8-1.2)$ & 2.0 & - & 1.3 \\
\hline \multicolumn{4}{|l|}{ Autoimmune antibodies } \\
\hline Anti-nuclear antibody & Negative & $1: 20$ & - \\
\hline Anti-smooth muscle antibody & Negative & - & - \\
\hline Liver biopsy findings & & - & - \\
\hline \multicolumn{4}{|l|}{ Lobular } \\
\hline Necrosis & Central & - & - \\
\hline Infiltrates & Plasmacytic & - & - \\
\hline Other findings & Disarray, apoptosis & - & - \\
\hline \multicolumn{4}{|l|}{ Portal and periportal } \\
\hline Cholangiolar proliferation & Moderate & - & - \\
\hline Infiltrate severity & Moderate & - & - \\
\hline Infiltrate predominant type & Plasmacytic & - & - \\
\hline Fibrosis & Fibronecrosis & - & - \\
\hline
\end{tabular}

Table 5: Naranjo [8] Causality Scale for Adverse Drug Reactions.

\begin{tabular}{|c|c|c|c|}
\hline & Question/Scoring-Yes/No/Do not know or unavailable & Case 1 & Case 2 \\
\hline 1 & Are there previous conclusive reports on this reaction? $1 / 0 / 0$ & 0 & 0 \\
\hline 2 & $\begin{array}{l}\text { Did the adverse event appear after the suspected drug was } \\
\text { given? } 2 /-1 / 0\end{array}$ & 2 & 2 \\
\hline 3 & $\begin{array}{l}\text { Did the adverse reaction improve when the drug was } \\
\text { discontinued or a specific antagonist was given? } 1 / 0 / 0\end{array}$ & 1 & 1 \\
\hline 4 & $\begin{array}{l}\text { Did the adverse reaction appear when the drug was } \\
\text { readministered? } 2 /-1 / 0\end{array}$ & 0 & 0 \\
\hline 5 & $\begin{array}{l}\text { Are there alternative causes that could have caused the reaction? } \\
-1 / 2 / 0\end{array}$ & -1 & -1 \\
\hline 6 & Did the reaction reappear when a placebo was given? $-1 / 1 / 0$ & 0 & 0 \\
\hline 7 & $\begin{array}{l}\text { Was the drug detected in any body fluid in toxic concentrations? } \\
1 / 0 / 0\end{array}$ & 0 & 0 \\
\hline 8 & $\begin{array}{l}\text { Was the reaction more severe when the dose was increased/ } \\
\text { increasing, or less severe when the dose was decreased? } 1 / 0 / 0\end{array}$ & 1 & 1 \\
\hline 9 & $\begin{array}{l}\text { Did the patient have a similar reaction to the same or similar } \\
\text { drugs in any previous exposure? } 1 / 0 / 0\end{array}$ & 0 & 0 \\
\hline & Total score & 3 & 3 \\
\hline
\end{tabular}

Scoring: $>9$ : definite adverse drug reaction (ADR).

$5-8$ : probable ADR.

1-4 : possible ADR

0 : doubtful ADR. 


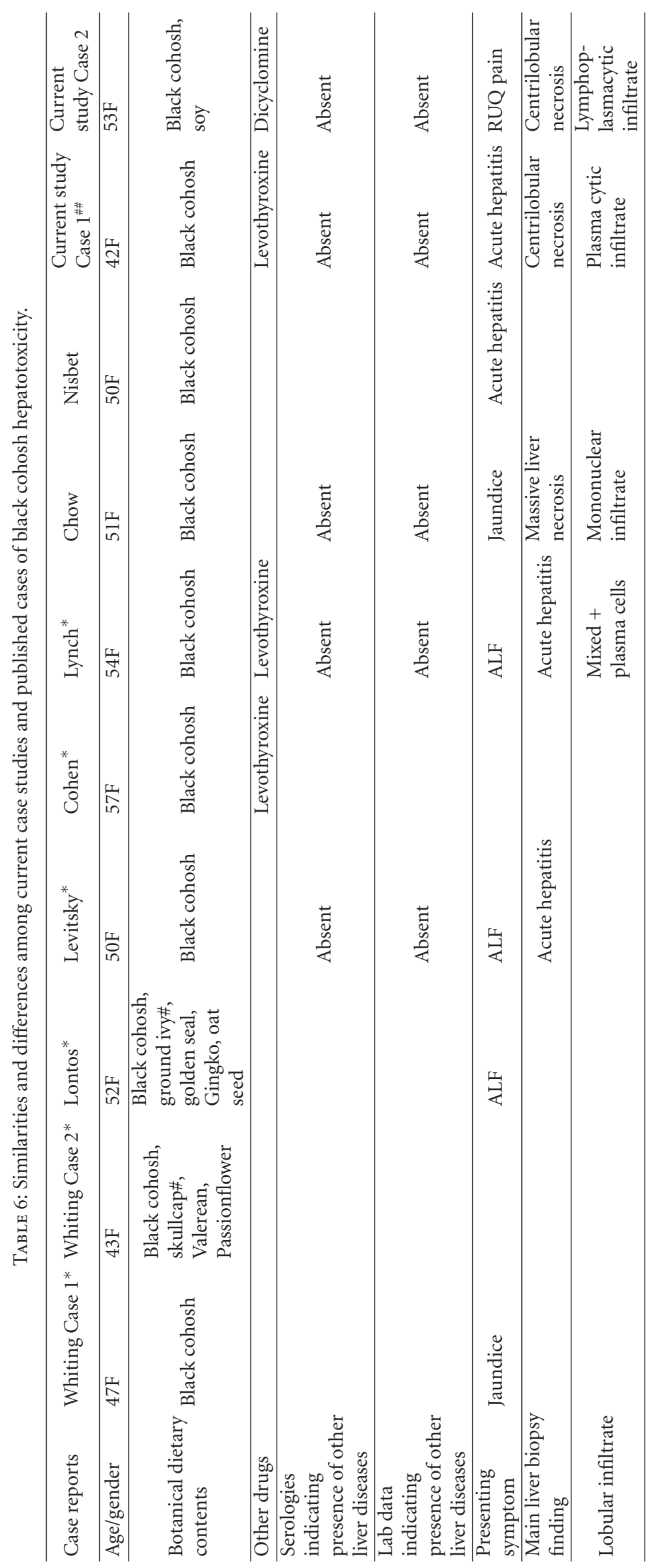




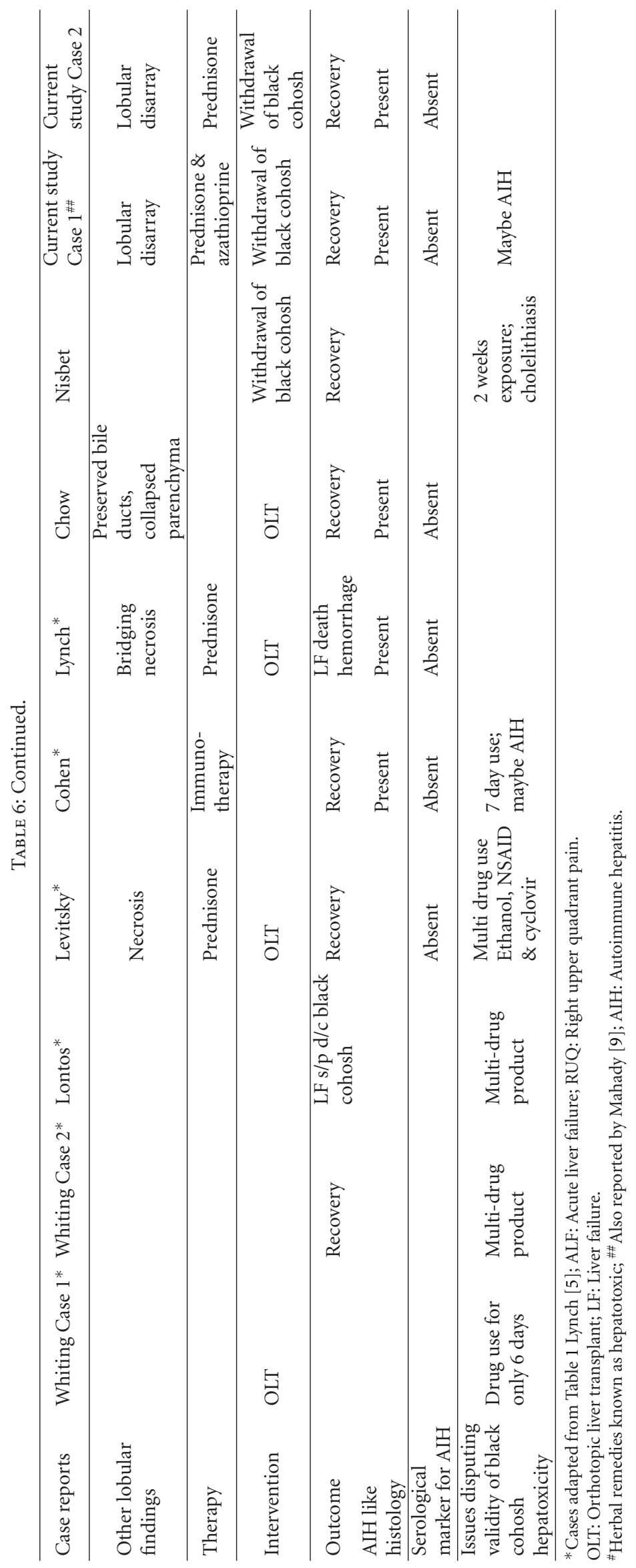


triggered the adverse drug reaction $[3,4,7]$, or the notion that some of the reported cases [2], including Case 1 of the current study (also reported by Mahady [23]), were indeed examples of autoimmune hepatitis rather than adverse drug reactions. Nonetheless, application of the Naranjo causality score to these case reports found possible cause for adverse drug reaction [8]. Further, autoimmune hepatitis is one of the known outcomes of drug-induced liver injury. The immune mechanism is precipitated by a drug or a metabolite acting as a hapten covalently binding to host cellular protein, converting into an immunogen [24] and thereby eliciting an autoimmune response. Outcomes illustrating an association of chronic hepatitis with autoimmune features developing following the use of the botanical supplement black cohosh need to be emphasized.

\section{Conclusion}

Here we described two cases of liver injury following the use of black cohosh characterized by chronic hepatitis with centrilobular necrosis and an interface activity dominated by plasma cells. While the histopathology in both cases was compatible with autoimmune hepatitis, clinical evidence for an autoimmune etiology was lacking. Nonetheless both cases improved upon withdrawal of the drug and immunosuppressive therapy, indicating that there was at least in part a drug-induced immunological basis to the liver injury.

The current case studies, and three other published cases of liver injury following the use of black cohosh, share similar histological characteristics [1, 2, 5]. Hepatic manifestations following the use of black cohosh should therefore be added to the list of differential diagnoses of hepatic necrosis culminating in chronic hepatitis mimicking autoimmune hepatitis.

\section{References}

[1] E. C. Chow, M. Teo, J. A. Ring, et al., "Liver failure associated with the use of black cohosh for menopausal symptoms," Medical Journal of Australia, vol. 188, no. 7, pp. 420-422, 2008.

[2] S. M. Cohen, A. M. O'Connor, J. Hart, et al., "Autoimmune hepatitis associated with the use of black cohosh: a case study," Menopause, vol. 11, no. 5, pp. 575-577, 2004.

[3] J. Levitsky, T. A. Alli, J. Wisecarver, et al., "Fulminant liver failure associated with the use of black cohosh," Digestive Diseases and Sciences, vol. 50, no. 3, pp. 538-539, 2005.

[4] S. Lontos, R. M. Jones, P. W. Angus, et al., "Acute liver failure associated with the use of herbal preparations containing black cohosh," Medical Journal of Australia, vol. 179, no. 7, pp. 390391, 2003.

[5] C. R. Lynch, M. E. Folkers, and W. R. Hutson, "Fulminant hepatic failure associated with the use of black cohosh: a case report," Liver Transplantation, vol. 12, no. 6, pp. 989-992, 2006.

[6] B. C. Nisbet and R. E. O'Connor, "Black cohosh-induced hepatitis," Delaware Medical Journal, vol. 79, no. 11, pp. 441444, 2007.

[7] P. W. Whiting, A. Clouston, and P. Kerlin, "Black cohosh and other herbal remedies associated with acute hepatitis," Medical Journal of Australia, vol. 177, no. 8, pp. 440-443, 2002.
[8] C. A. Naranjo, U. Busto, E. M. Sellers, et al., "A method for estimating the probability of adverse drug reactions," Clinical Pharmacology and Therapeutics, vol. 30, no. 2, pp. 239-245, 1981.

[9] G. B. Mahady, T. L. Dog, M. L. Barrett, et al., "United States Pharmacopeia review of the black cohosh case reports of hepatotoxicity," Menopause, vol. 15, no. 4, pp. 628-638, 2008.

[10] E. M. Hennes, M. Zeniya, A. J. Czaja, et al., "Simplified criteria for the diagnosis of autoimmune hepatitis," Hepatology, vol. 48, no. 1, pp. 169-176, 2008.

[11] J. D. Lewis and B. L. Strom, "Balancing safety of dietary supplements with the free market," Annals of Internal Medicine, vol. 136, no. 8, pp. 616-618, 2002.

[12] D. M. Eisenberg, R. B. Davis, S. L. Ettner, et al., "Trends in alternative medicine use in the United States, 1990-1997: results of a follow-up national survey," Journal of the American Medical Association, vol. 280, no. 18, pp. 1569-1575, 1998.

[13] B. Jiang, F. Kronenberg, P. Nuntanakorn, et al., "Evaluation of the botanical authenticity and phytochemical profile of black cohosh products by high-performance liquid chromatography with selected ion monitoring liquid chromatography-mass spectrometry," Journal of Agricultural and Food Chemistry, vol. 54, no. 9, pp. 3242-3253, 2006.

[14] V. Viereck, G. Emons, and W. Wuttke, "Black cohosh: just another phytoestrogen?" Trends in Endocrinology and Metabolism, vol. 16, pp. 214-221, 2005.

[15] ACOG Practice Bulletin, "Clinical management guidelines for obstetrician-gynecologists. Use of botanicals for management of menopausal symptoms," Obstetrics and Gynecology, vol. 97, no. 6, supplement, pp. 1-11, 2001.

[16] K. M. Newton, S. D. Reed, A. Z. LaCroix, et al., "Treatment of vasomotor symptoms of menopause with black cohosh, multibotanicals, soy, hormone therapy, or placebo: a randomized trial," Annals of Internal Medicine, vol. 145, no. 12, pp. 869879, 2006.

[17] F. Kronenberg and A. Fugh-Berman, "Complementary and alternative medicine for menopausal symptoms: a review of randomized, controlled trials," Annals of Internal Medicine, vol. 137, no. 10, pp. 805-813, 2002.

[18] P. A. De Smet, A. J. Van den Eertwegh, W. Lesterhuis, et al., "Hepatotoxicity associated with herbal tablets," British Medical Journal, vol. 313, no. 7049, p. 92, 1996.

[19] H. E. Gouda, A. Khan, J. Schwartz, et al., "Liver failure in a patient treated with long-term rosiglitazone therapy," American Journal of Medicine, vol. 111, no. 7, pp. 584-585, 2001.

[20] N. L. Sheehan, M. J. Brouillette, M. S. Delisle, et al., "Possible interaction between lopinavir/ritonavir and valproic acid exacerbates bipolar disorder," The Annals of Pharmacotherapy, vol. 40, pp. 147-150, 2006.

[21] M. Touzot, C. Le Beller, F. Touzot, et al., "Dramatic interaction between levothyroxine and lopinavir/ritonavir in a HIVinfected patient," AIDS, vol. 20, no. 8, pp. 1210-1212, 2006.

[22] A. Tseng and D. Fletcher, "Interaction between ritonavir and levothyroxine,” AIDS, vol. 12, no. 16, pp. 2235-2236, 1998.

[23] G. B. Mahady, D. Fabricant, L. R. Chadwick, et al., "Black cohosh: an alternative therapy for menopause?" Nutrition in Clinical Care, vol. 5, pp. 283-289, 2002.

[24] W. Bleibel, S. Kim, K. D’Silva, and E. R. Lemmer, "Druginduced liver injury: review article," Digestive Diseases and Sciences, vol. 52, no. 10, pp. 2463-2471, 2007. 


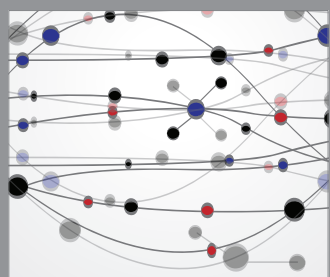

The Scientific World Journal
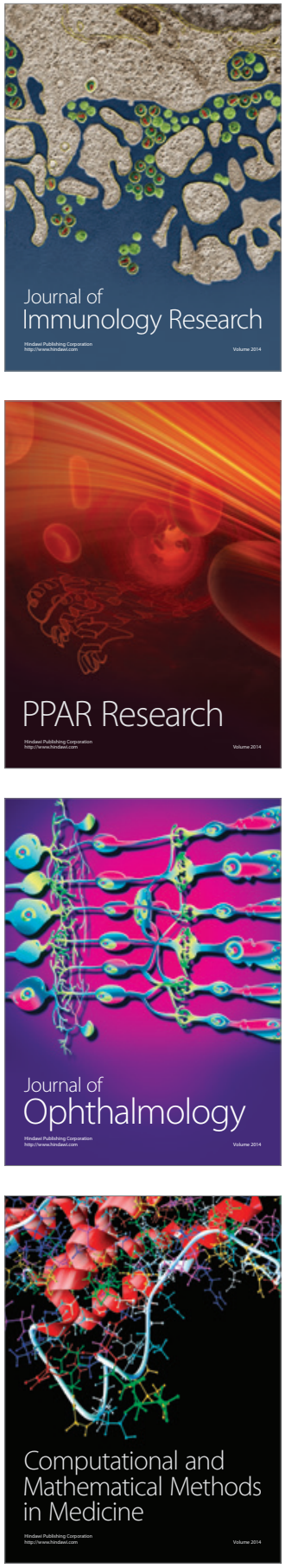

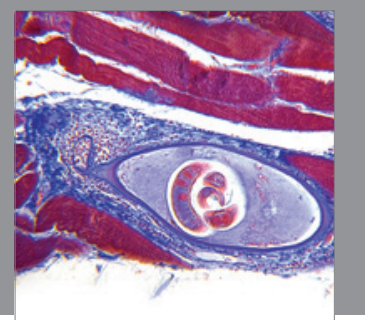

Gastroenterology

Research and Practice
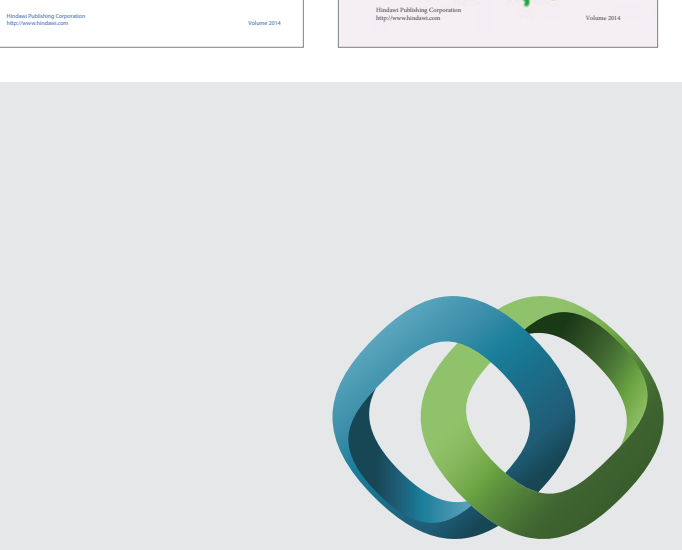

\section{Hindawi}

Submit your manuscripts at

http://www.hindawi.com
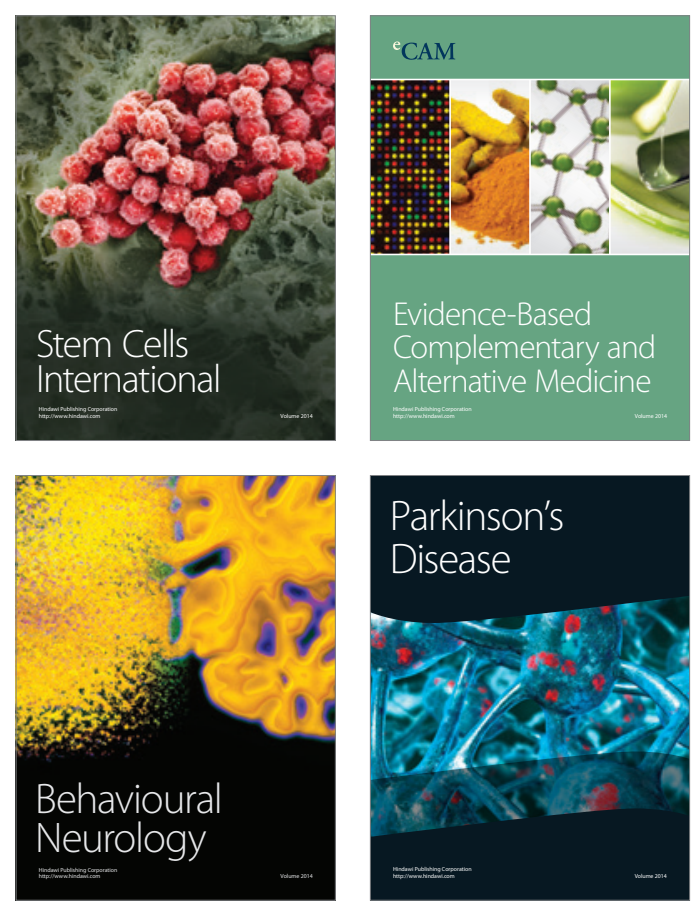

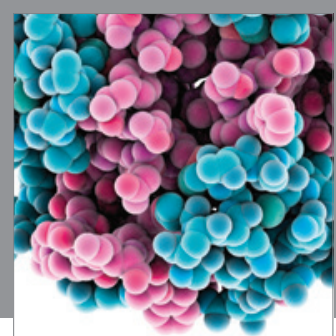

Journal of
Diabetes Research

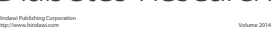

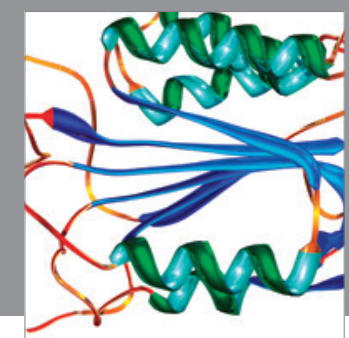

Disease Markers
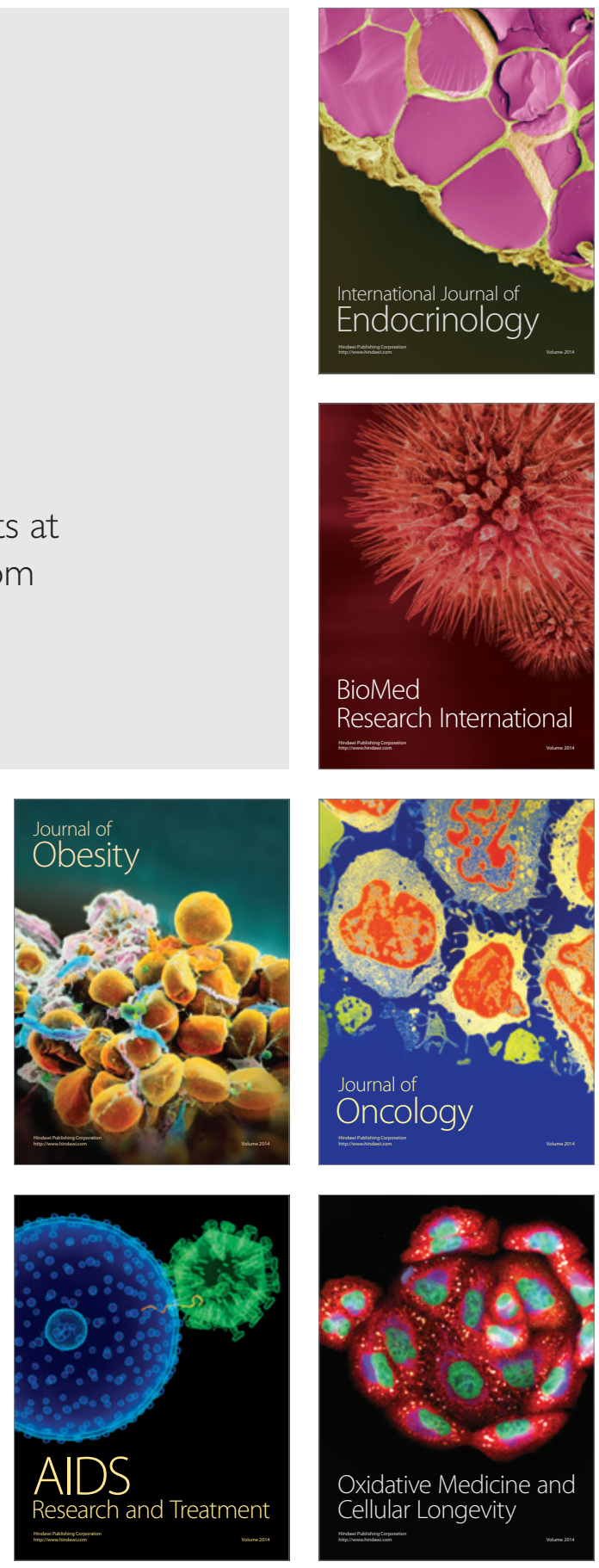